Artikel Penelitian

\title{
Efektifitas Frekuensi Ekstraksi Serta Pengaruh Suhu dan Cahaya Terhadap Antosianin dan Daya Antioksidan Ekstrak Kelopak Rosela (Hibiscus sabdariffa L.)
}

\section{Extraction Frequency Effectiveness and Effect of Temperature and Light on Anthocyanin and Antioxidant Capacity of Rosella Petal Extract (Hibiscus sabdariffa L.)}

Suharyani Amperawati ${ }^{1}$, Pudji Hastuti ${ }^{2}$, Yudi Pranoto ${ }^{2}$, Umar Santoso ${ }^{2 *}$

${ }_{1}^{1}$ Program Studi Teknologi Pengolahan Hasil Perkebunan, Jurusan Teknologi Pertanian, Politeknik Negeri Pontianak, Pontianak ${ }^{2}$ Departemen Teknologi Pangan dan Hasil Pertanian, Fakultas Teknologi Pertanian, Universitas Gadjah Mada, Yogyakarta

*Korespodensi dengan penulis (umar_santoso@ugm.ac.id)

Artikel ini dikirim pada tanggal 8 November 2018 dan dinyatakan diterima tanggal 23 Februari 2019. Artikel ini juga dipublikasi secara online melalui https://ejournal2.undip.ac.id/index.php/jatp. Hak cipta dilindungi undang-undang. Dilarang diperbanyak untuk tujuan komersial.

Diproduksi oleh Indonesian Food Technologists® @ $(2019$

\begin{abstract}
Abstrak
Penelitian ini bertujuan untuk mengetahui kualitas dan kadar antosianin ekstrak kelopak rosela dari perlakuan ekstraksi dengan maserasi pada beberapa kali ekstraksi, serta mempelajari pengaruh suhu dan pemaparan cahaya selama penyimpanan terhadap kadar antosianin dan daya antioksidan. Ekstraksi kelopak rosela dilakukan sebanyak 4 kali dengan metode maserasi. Pengaruh penyimpanan dengan suhu $30,40,50,60$ dan $70^{\circ} \mathrm{C}$ selama $7,14,21,28$, dan 35 hari. Pemaparan cahaya dilakukan dengan 1478, 2835, dan 3940 lux dan sebagai pembanding digunakan perlakuan tanpa pencahayaan selama 1 sampai dengan 10 hari. Parameter untuk ektraksi meliputi kadar antosianin, warna $\left(L^{*}, a^{*}, b^{*}, \Delta \mathrm{E}\right)$, dan total padatan terlarut. Parameter penyimpanan meliputi kadar antosianin dan daya antioksidan metode radical scavenging (DPPH). Hasil peneltian menunjukkan bahwa ekstraksi ke 1, 2, 3, dan 4 kali menunjukkan kadar antosianin masing-masing 608, 218, 64, dan $32 \mathrm{mg} / \mathrm{l}$; nilai $L^{*}$ sebesar 29,07; 32,27; 36,19; dan 45,27; nilai $a^{*}$ sebesar 10,42; 16,33; 21,90 dan 15,63; dan $b^{*}$ adalah 1,$36 ; 4,56$; 8,33; dan 5,86; $\Delta \mathrm{E}$ adalah 1,31 ; 7,53; 15,29; dan 18,06. Ekstraksi lebih baik dilakukan 2 kali, sedangkan ekstraksi yang ke-3 dan 4 menghasilkan kadar antosianin yang relatif kecil. Hasil penelitian juga menunjukkan bahwa makin tinggi suhu dan lama penyimpanan menyebabkan kandungan antosianin dan kapasitas antioksidan makin menurun, demikian pula makin tinggi intensitas cahaya menyebabkan makin menurunnya kadar antosianin dan kemampuan antioksidannya. Kesimpulannya, berdasarkan semua parameter yang diukur maka ekstraksi dapat dilakukan sampai dengan 2 kali dan guna menjaga antosianin dan antioksidannya, maka sebaiknya disimpan dalam ruang dingin dan terhindar dari cahaya matahari.
\end{abstract}

Kata kunci : rosela, ekstraksi, suhu, cahaya, antioksidan

\section{Abstract}

This study aims to determine the quality and levels of anthocyanin roselle petal extract from extraction treatment with maceration frequency and to determine the effect of temperature and light exposure during storage on anthocyanin levels and antioxidant activity. Roselle petal extraction was carried out 4 times with maceration method. Storage condition were set up at 30,40,50,60, and $70^{\circ} \mathrm{C}$ for $7,14,21,28$, and 35 days. Light exposure was conducted using 1478, 2835, and 3940 lux and as a comparison, the extract was kept without light from 1 to 10 days. The parameters for extraction were anthocyanin, color levels $\left(L^{*}, a^{*}, b^{*}, \Delta E\right)$, and total soluble solids. Storage parameters were anthocyanin content and antioxidant capacity of the radical scavenging (DPPH) method. The results of anthocyanin levels of extraction 1, 2, 3, and 4 times were 608, 218, 64, and $32 \mathrm{mg} / \mathrm{L} ; 29.07,32.27,36.19$, and 45.27 for $L^{*}, 10.42,16.33,21.90$ and 15.63 for $a^{*}$ value, 1.36, 4.56, 8.33, and 5.86 for $b^{*}$ value, 1,31; 7,53; 15,29; and 18,06 for $\triangle E$, respectively. Twice extraction was provide much better result for total anthocyanin, while $3 r d$ and 4th extractions produced relatively small level of anthocyanin. The results also showed that the higher temperature and storage time, the decrease in anthocyanin content and antioxidant capacity. The higher intensity of the light caused reduction of anthocyanin content and its antioxidant activity. As conclusion, roselle extract might be conducted for two times. The storage was also suggested at low temperatures and low exposure light to keep its anthocyanin and antioxidant.

Keywords: rosella, extraction, temperature, light, antioxidant

\section{Pendahuluan}

Rosela atau Hibiscus sabdariffa L., merupakan tanaman yang cocok diusahakan di negara-negara tropis karena relatif mudah tumbuh dan berkembang, juga dapat digunakan sebagai makanan dan serat (DaCosta-Rocha, 2014 dan Inggrid et al., 2017). Kelopak rosela segar atau kering banyak digunakan dalam pembuatan minuman herbal, minuman panas dan dingin, minuman fermentasi, wine, selai, jellied confectionaries, es krim, cokelat, flavouring agents, puding dan kue (Da-Costa-Rocha, 2014). Antosianin adalah subkelompok flavonoid pada tanaman yang sebagian besar dalam bentuk glikosida sebagai antosianidin (Santoso, 2016., Sindi et al., 2014; Faria et 
al., 2013). Antosianin adalah pigmen larut dalam air (Delgado-Vargas et al., 2003; Boas, 2014), selanjutnya Delgado-Vargas (2003) juga menyebutkan bahwa antosianin besifat vakoular yang berada dalam sel epidermis pada bunga tetapi juga terdapat dalam sel mesofil yaitu pada daun gandum (Secale cereale) dan dapat ditemukan dalam kelopak rosela yang dapat menyebabkan warna merah keunguan. Senyawa utama yang ditemukan dalam kelopak rosela adalah asam organik, terutama asam sitrat, asam malat, dan antosianin, juga ditemukan flavonoid dan glikosida, serta serat (Ali et al., 2005; Sayago-Ayerdi et al., 2007).

Kelopaknya yang berwarna merah disebabkan oleh senyawa antosianin yang dikandungnya, yaitu: delphinidin-3-sambubioside, cyanidin-3-sambubioside, cyanidin-3-glucoside dan delphinidin-3-glucoside (Castaneda-Ovando et al., 2009), selain itu Sindi et al., 2014 dalam penelitiannya terhadap kelopak rosella menemukan keberadaan delphinidin 3-glucoside dan delphinidin 3-sambubioside, yang memiliki 3 grup hidroksil pada ring $B$, dan cyanidin 3-glucoside and cyanidin 3-sambubioside, dimana keduanya juga memiliki 2 grup hidroksil pada ring B. Antosianin kelopak rosella, khususnya delphinidin-3-sambubioside dan cyanidin-3-sambubioside merupakan senyawa aktif utama yang berperan untuk anti-hipertensi, antioksidan, dan efek hipokolesterolemik, jumlahnya relatif cukup tinggi di dalam ekstrak (McKay et al., 2010; Herrera et al., 2007).

Antosianin biasa digunakan dalam industri makanan sebagai bahan antioksidan dan pengganti pewarna sintetis karena warnanya yang cerah dan menarik serta kelarutan yang tinggi dalam air, sehingga memungkinkan untuk diaplikasikan ke dalam sistem pangan (Castaneda-Ovando et al., 2009; Cissé, 2012; Boas, 2014; Inggrid et al., 2017). Selain warna merahnya yang menarik, antosianin terasa asam dan menyegarkan.

Senyawa antosianin dapat menangkap dan menetralisir radikal bebas pada tubuh maupun pangan, sehingga sangat bermanfaat bagi kesehatan serta dapat mengurangi bahkan mencegah kerusakan pangan, namun aplikasinya sering terbatas karena stabilitas kimia yang rendah (Castaneda-Ovando et al., 2009 dan loannou et al., 2012). Warna dan stabilitas antosianin berkaitan dengan keberadaan beberapa ikatan ganda dalam strukturnya, sehingga dapat dikatakan bahwa struktur adalah penyebab ketidakstabilan antosianin (Delgado-Vargas, 2003). Bahkan Markakis (1982) juga menyatakan bahwa antosianin memiliki struktur yang sangat tidak stabil baik dalam jaringan tanaman maupun produk makanan. Fernandes et al. (2014) juga mengatakan bahwa antosianin dapat terdegradasi melalui beberapa proses yang terjadi baik selama ekstraksi, pengolahan dan penyimpanan makanan. Menurut Elbe dan Schwartz (1996) dan Fernandes et al. (2014), kerusakan antosianin dipengaruhi oleh faktor suhu, pH, cahaya, oksigen dan enzim. Proses dekomposisi antosianin lebih cepat terjadi jika mengalami kenaikan temperatur (Patras et al., 2010). Demikian pula yang dikatakan oleh Lestario (2017), bahwa antosianin tidak stabil pada intensitas cahaya dan suhu tinggi serta larutan aqueous. Lepasnya gugus gula menyebabkan aglikon antosianin yang terbentuk cepat memudar warnanya jika terkena sinar atau peningkatan temperatur (Janna et al., 2006).

Senyawa antosianin dapat diisolasi dari jaringan tanaman dengan cara mengekstrak jaringan tumbuhan tersebut menggunakan pelarut organik (Mahfud, 2018). Kandungan antosianin yang terdapat di dalam limbahnya yang berupa ampas hasil penyaringan pertama ektrak kelopak rosela masih cukup tinggi dimana terlihat warna merahnya masih kuat sehingga memungkinkan untuk diekstrak kembali karena diperkirakan kandungan antosianinnya masih cukup tinggi seperti yang terlihat pada Figur 4a. Penelitian mengenai ekstraksi kelopak rosella telah banyak dilakukan, namun mengenai berapa kali frekuensi ekstraksi yang paling baik atau efektif, dinilai masih sangat terbatas, sehingga melalui penelitian ini diharapkan dapat ditentukan sampai berapa kali frekuensi ekstraksi yang terbaik dapat dilakukan terhadap kelopak rosella. Selain itu, antosianin yang dihasilkan dari ekstraksi tersebut bersifat tidak stabil dan mudah mengalami degradasi sehingga berdasarkan hal tersebut peneliti juga merasa perlu untuk mengetahui sejauh mana suhu dan cahaya berpengaruh terhadap kandungan antosianin dan daya antioksidan kelopak rosela.

\section{Materi dan Metode \\ Materi}

Kelopak segar rosella diperoleh dari Pontianak, Kalimantan Barat. Bahan kimia yang digunakan adalah radikal bebas 2,2-diphenyl-1-picrylhydrazyl (DPPH), asam sitrat, kalium klorida, natrium asetat, metanol adalah kelas analitis dari Sigma-Aldrich. Aquadest dibeli dari General Laboratorium Yogyakarta. Alat yang digunakan meliputi Freeze dryer (Alpha 1-2 LD, Germany), blender, lux-meter (Extech-Instruments, Taiwan), rotary evaporator (Laborota 4000, Singapore), hand refractometer (ATAGO, Jepang), inkubator (Eyela Natural sterilizer NDS-601D, Japan), kotak pencahayaan (ukuran 47x47x60 $\mathrm{cm}$ ), spectrophotometer (Thermo Scientific Genesis 10S-UVVIS, USA), kolorimeter (Minolta type CR-400, Japan), dan mikropipet.

\section{Metode}

Penelitian ini berlangsung pada bulan Maret sampai Juli 2017 di Laboratorium Rekayasa Proses Fakultas Teknologi Pertanian Universitas Gadjah Mada Yogyakarta. Kelopak rosella segar dikeringkan selama 10 hari dilanjutkan dengan pengeringan beku. Penelitian meliputi ekstraksi kelopak rosella yang dilakukan pengulangan 1 sampai 4 kali dengan metode maserasi, analisis komponen antosianin, analisis pengaruh suhu dan cahaya terhadap kandungan antosianin dan daya antioksidan ekstrak kelopak rosella. Uji yang dilakukan terhadap ekstrak kelopak rosella pada proses ekstraksi meliputi kadar antosianin, warna, dan total soluble solid (TSS). Analisis pengaruh suhu dan cahaya selama 
penyimpanan meliputi kadar antosianin dan daya antioksidan dengan metode DPPH $(\%$ radical scavenging activity).

\section{Ekstraksi Kelopak Rosela}

Serbuk kelopak bunga rosella diekstraksi menggunakan pelarut aquades asam (asam sitrat 2\%) mengikuti Abou-Arab (2011) pada rasio 1: 10 dan dimaserasi di ruangan gelap pada $4^{\circ} \mathrm{C}$ selama 24 jam, kemudian disaring (ekstraksi pertama), perlakuan yang sama diulang terhadap ampas yang dihasilkan untuk ekstraksi yang ke-2 sampai dengan ke-4. Selanjutnya masing-masing ekstrak tersebut dianalisis kadar antosianin, warna, dan TSS, setelah itu dievaluasi sampai berapa kali proses ekstraksi yang paling baik dan efisien, kemudian ekstrak itu dipekatkan.

Ekstrak dipekatkan dengan rotary evaporator pada suhu $45^{\circ} \mathrm{C}$ selama 5 jam, setelah itu ekstrak disimpan dalam wadah yang dilapisi aluminium foil pada suhu $-18^{\circ} \mathrm{C}$ hingga penggunaan berikutnya. Untuk mengetahui pengaruh suhu dan cahaya selama penyimpanan, maka ekstrak diencerkan dengan aquades $(6,7 \mathrm{ml} / 1000 \mathrm{ml})$.

\section{Pengaruh Penyimpanan}

Untuk mengetahui pengaruh suhu disiapkan sebanyak $15 \mathrm{ml}$ ekstrak yang telah diencerkan dengan aquades dimasukkan ke dalam tabung screw-tub $(20 \mathrm{ml})$ kemudian ditutup dengan aluminium foil dan ditempatkan dalam inkubator (Eyela Natural sterilizer NDS-601D) dengan suhu $30,40,50,60$, dan $70^{\circ} \mathrm{C}$ dan diamati pada 7, 14, 21, dan 28 hari; sedangkan untuk mengetahui pengaruh cahaya, maka tabung screw-tub tersebut ditempatkan pada kotak pencahayaan dan jarak lampu sebagai sumber cahaya dengan sampel adalah $40 \mathrm{~cm}$, lampu yang digunakan adalah lampu merek Philips (essential) dengan 3 variasi intensitas cahaya yaitu 1478, 2835, dan 3840 lux dengan tabung tertutup aluminium foil sebagai pembanding kemudian pengamatan dilakukan setiap 24 jam selama 10 hari.

\section{Penentuan Kadar Antosianin}

Penentuan total antosianin dengan metode $\mathrm{pH}$ diferensial seperti yang dikemukakan oleh Wrolstad (2005). Absorbansi setiap larutan diukur pada panjang gelombang $\lambda 510$ dan $700 \mathrm{~nm}$, dengan buffer $\mathrm{pH} 1$ dan 4,5 sebagai blangko menggunakan spectrophotometer. Absorbansi sampel yang telah dilarutkan $(\mathrm{A})$ ditentukan dengan menghitung selisih absorbansi $\mathrm{pH}$ 1,0 pada panjang gelombang 510 dan 700 dikurangi dengan selisih absorbansi pH 4,5 pada panjang gelombang 510 dan 700 . Total antosianin (mg/liter) pada sampel dihitung sebagai kandungan pigmen sianidin-3-glikosida dengan formula $(A \times M W \times D F \times 1000) /(\varepsilon \times L)$, dimana $\varepsilon$ adalah absorptivitas molar Sianidin-3-glukosida sebesar 26900 $\mathrm{L} /(\mathrm{mol} . \mathrm{cm}), \mathrm{L}$ adalah lebar kuvet yaitu $1 \mathrm{~cm}, \mathrm{MW}$ adalah berat molekul Sianidin-3- glukosida sebesar $449,2 \mathrm{~g} / \mathrm{mol}$, DF adalah faktor pengenceran, $V$ adalah volume akhir atau volume ekstrak pigmen (L), dan Wt adalah berat bahan awal (g).
Pengukuran warna

Pengukuran warna kelopak rosella meliputi (i) lightness $\left(L^{*}\right)$, (ii) redness/greenness $\left(a^{*}\right)$, and (iii) blueness/yellowness $\left(b^{*}\right)$. Pengukuran warna menggunakan Colorimetric. Untuk lebih memahami perubahan warna pada ekstrak rosella, total colour differential $(\Delta \mathrm{E})$ dihitung dengan menggunakan rumus dari peneliti sebelumnya (Shin et al., 1995), yaitu merupakan akar dari $\Delta L^{\star^{2}}+\Delta \mathrm{a}^{\star^{2}}+\Delta \mathrm{b}^{\star 2}$.

\section{Pengukuran total padatan terlarut}

Total padatan terlarut atau TSS ditentukan dalam unit ${ }^{\circ}$ Brix dan dilakukan sesuai dengan AOAC (2000) yang dibantu dengan alat hand refractometer.

\section{Penentuan Aktivitas Antioksidan}

Aktivitas antioksidan diketahui melalui pengujian kapasitas penangkapan radikal bebas menggunakan DPPH. Sampel sebanyak 0,2 ml ditambahkan 3,8 ml larutan $0,1 \mathrm{mM}$ DPPH kemudian divortek selama 1 menit. Setelah itu diinkubasi di ruang gelap pada suhu kamar, setelah 30 menit dan diamati absorbansinya menggunakan spektrofotometer pada panjang gelombang $517 \mathrm{~nm}$ (Abou-Arab et al., 2011). Daya tangkap radikal bebas atau Radical Scavenging Activity (\%) dihitung melalui formula [1- (Abs sampel/Abs blangko)] x 100, dimana prosentase RSA menunjukkan persentase pemucatan $\mathrm{DPPH}$.

\section{Analisis Statistik}

Semua data penelitian diperoleh dengan tiga kali ulangan yang disajikan dalam rata-rata dan dianalisis secara statistik melalui metode one-way ANOVA menggunakan Software SPSS Statistics versi 21.0 dengan tingkat signifikansi sebesar $a=0,05$.

\section{Hasil dan Pembahasan}

\section{Efektivitas Frekuensi Ekstraksi}

Ekstraksi adalah pemisahan berdasarkan sifat kelarutan suatu senyawa dalam suatu pelarut melalui perpindahan atau transfer zat dari suatu fasa ke fasa yang lainnya (Wells, 2003) Peristiwa larutnya senyawa terjadi karena adanya gaya tarik antar molekul pelarut dengan molekul zat terlarut, senyawa polar larut dalam pelarut polar dan senyawa non polar larut dalam pelarut non polar (Doyle, 1980). Antosianin adalah molekul yang bersifat polar sehingga lebih larut dalam pelarut polar daripada dalam pelarut non polar (Delgado-Vargas, 2003; Cissé, 2012). Tujuan utama ekstraksi kelopak rosela adalah untuk mendapatkan antosianin semaksimal mungkin secara efektif berdasarkan frekuensi ekstraksinya. Pada penelitian ini dilakukan beberapa kali ekstraksi terhadap kelopak rosela untuk mendapatkan antosianin dan hasilnya dibandingkan untuk mengetahui sampai berapa kali frekuensi ekstraksi yang paling efektif.

Figur 1 memperlihatkan bahwa total kadar antosianin yang dihasilkan dari 4 kali ekstraksi adalah $921,56 \mathrm{mg} / \mathrm{l}$. Antosianin tertinggi dihasilkan dari ekstraksi pertama sebesar $65,93 \%$, kemudian yang ekstraksinya dilakukan sebanyak 2, 3, dan 4x masing-masing sebesar 
23,70; 6,91; dan 3,45\%. Terlihat bahwa antosianin pada ekstraksi yang ke-3 dan 4, kadar antosianin yang dihasilkannya terlalu sedikit (total hanya 10,36\%). Proses ektraksi dapat lebih efektif bila dilakukan sampai 2 kali saja dengan total antosianin yang dihasilkan dinilai tinggi yaitu sebesar $89,64 \%$. Berdasarkan hal ini maka untuk penelitian selanjutnya ekstrak kelopak rosela dengan frekuensi 2 kali ekstraksi saja kemudian hasilnya digabungkan dalam satu wadah dan disimpan sampai penelitian berikutnya.

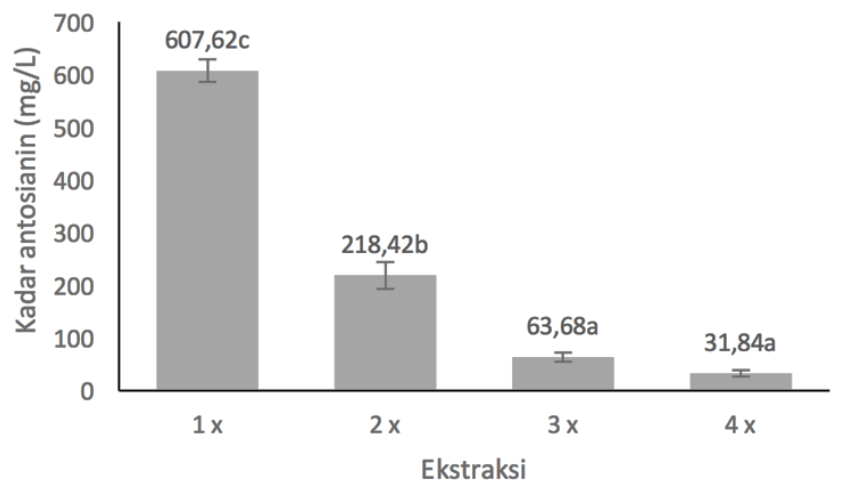

Figur 1. Kadar antosianin ekstrak rosela pada berbagai kali ekstraksi

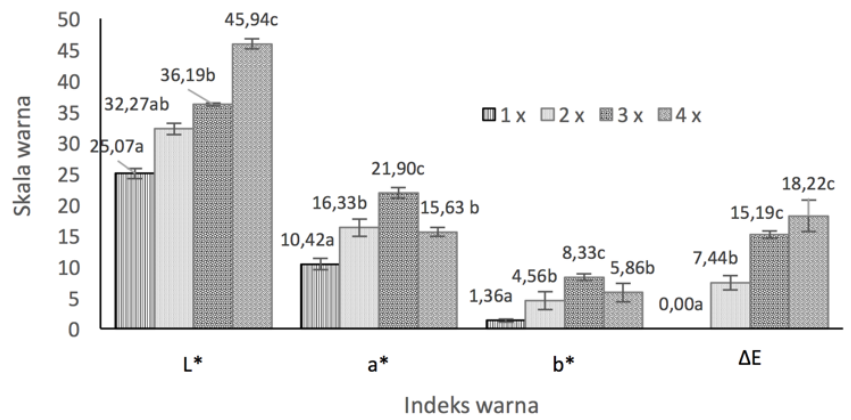

Figur 2. Perubahan warna ekstrak rosela berdasarkan metode perhitungan $L^{*} a^{*} b^{\star}$ dan $\Delta \mathrm{E}$ pada empat kali ekstraksi

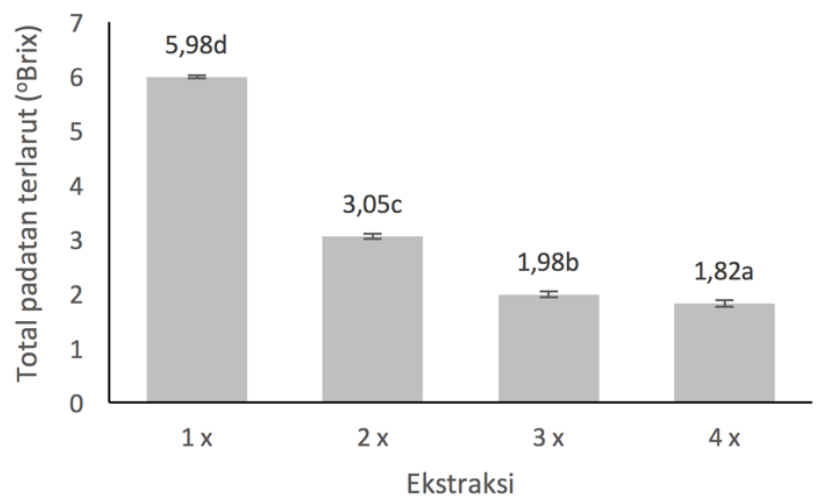

Figur 3. Total padatan terlarut ekstrak kelopak rosela dari beberapa kali ekstraksi

Nilai warna yang terlihat pada Figur 2 diperoleh berdasarkan CIE Lab color yang digambarkan dengan tiga komponen warna yaitu lightness $\left(L^{*}\right)$ dengan nilai 0 berarti hitam/gelap dan 100 adalah intensitas cahaya maksimum yang dapat terlihat; redness $\left(a^{*}\right)$ adalah bidang warna hijau-merah $(-128,+127)$, dan yellowness $\left(b^{\star}\right)$ adalah bidang warna biru-kuning $(-128,+127)$, sedangkan pada bagian tengah $(a *=0 ; b *=0)$ bernilai abu-abu, semua warna dapat terlihat dan dibedakan oleh penglihatan manusia (Vatai, 2008; Mokrzycki, 2012). Parameter $L^{*}$ menunjukkan perbedaan yang nyata $(P>0,05)$. Nilai $L^{*}$ meningkat dari 25,07 menjadi 45,94 mulai ekstraksi pertama sampai ke empat yang mengindikasikan warna ekstrak yang dihasilkan terlihat semakin terang, namun antosianin dan total padatan terlarut yang dihasilkan, makin rendah seperti pada Figur 1 dan Figur 3.

Nilai $a^{*}$ pada ekstraksi yang pertama, kedua, dan ketiga mengalami peningkatan masing-masing 10,42; 16,33; dan 21,90, namun pada ekstraksi yang keempat tampak menurun $(15,63)$. Peningkatan nilai $a^{*}$ dan $b^{*}$ tidak sejalan dengan peningkatan kadar antosianin seperti pada Figur 1 namun kadar antosianin ekstraksi kesatu lebih besar dibandingkan yang kedua sampai dengan keempat. Hasil esktraksi pertama lebih pekat dari ekstraksi yang kedua dan ketiga sehingga warnanya terlihat lebih gelap atau merah kehijauan dan kuning kebiruan, akibatnya nilai $a^{\star}$ dan $b^{\star}$ yang terukur terlihat lebih rendah, walaupun kadar antosianinnya tinggi. Pada ekstraksi yang keempat komponen senyawa yang dapat terekstrak menurun sehingga total padatan terlarut dan kandungan antosianinnya berkurang sehingga nilai parameter $a^{\star}$ dan $b^{\star}$ nya menurun pula.

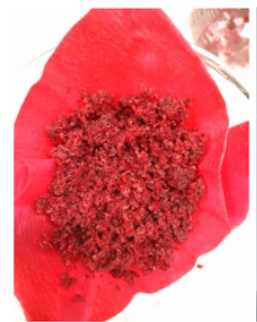

(a)

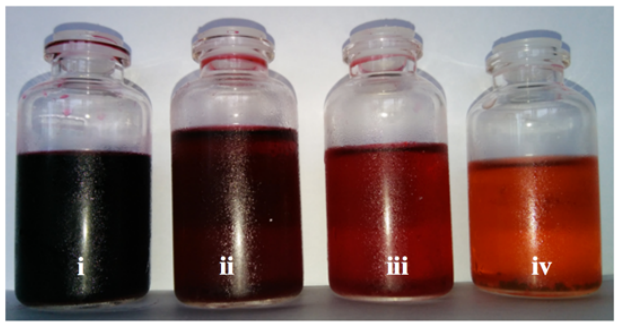

(b)
Figur 4. Foto hasil ekstraksi kelopak rosela : (a) ampas ekstraksi pertama; (b) ekstrak setelah melalui beberapa kali proses ekstraksi; (i) 1 kali, (ii) 2 kali, (iii) 3 kali, dan (iv) 4 kali.

Perbedaan warna $(\Delta \mathrm{E})$ antar ekstraksi pertama sampai keempat pada Figur 2 yang memperlihatkan bahwa perbedaan $\Delta \mathrm{E}$ semakin meningkat dan menunjukkan perbedaan yang nyata pada taraf signifikansi $5 \%$. Peningkatan $\Delta \mathrm{E}$ ini berkaitan erat dengan penurunan kadar antosianin dan total padatan terlarut sehingga menyebabkan perbedaan nilai $\Delta \mathrm{E}$ yang jelas antar perlakuan ekstraksi.

Seperti yang ditampilkan pada Figur 3, terlihat total padatan terlarut yang dihasilkan dari beberapa kali ekstraksi. Ekstraksi pertama sampai dengan keempat menunjukan total padatan terlarut yang semakin berkurang dan semua perlakuan menunjukkan perbedaan yang nyata antar perlakuan $(P>0,05)$. Semakin banyak frekuensi ekstraksi terhadap ampas kelopak rosella, maka senyawa yang dapat terekstrak juga menurun karena komponen senyawa antosianin yang dapat diekstrak dari ampas kelopak rosella yang terakhir diekstrak juga semakin kecil dibandingkan yang sebelumnya, sehingga berdasarkan total padatan 
terlarutnya, maka ekstraksi pertama $>$ kedua $>$ ketiga $>$ keempat.

Perbedaan warna ekstrak rosella secara visual pada setiap kali ekstraksi dapat dilihat pada Figur 4 yang secara jelas terlihat adanya perbedaan warna karena semakin sering ekstraksi dilakukan, maka warnanya terlihat semakin pudar dan terang karena kepekatannya juga berkurang sejalan dengan menurunnya kadar antosianin dan total padatan terlarut.

Semakin banyak dilakukan ekstraksi terhadap kelopak rosela, warna ekstrak yang dihasilkan terlihat semakin muda dan terang, dimana hasil ekstraksi pertama dan kedua terlihat jauh lebih pekat dari ekstraksi yang ketiga dan keempat. Total kadar antosianin pada dua kali ekstraksi, yaitu pertama dan kedua, sebesar 826,04 mg/l, yang jauh lebih tinggi dari pada total antosianin ketiga dan keempat, yang besarnya hanya 95,52 mg/l. Oleh karena itu, proses ekstraksi kelopak rosela lebih baik bila dilakukan sebanyak 2 kali saja walaupun masih ada antosianin yang tersisa pada ekstraksi ketiga dan keempat.

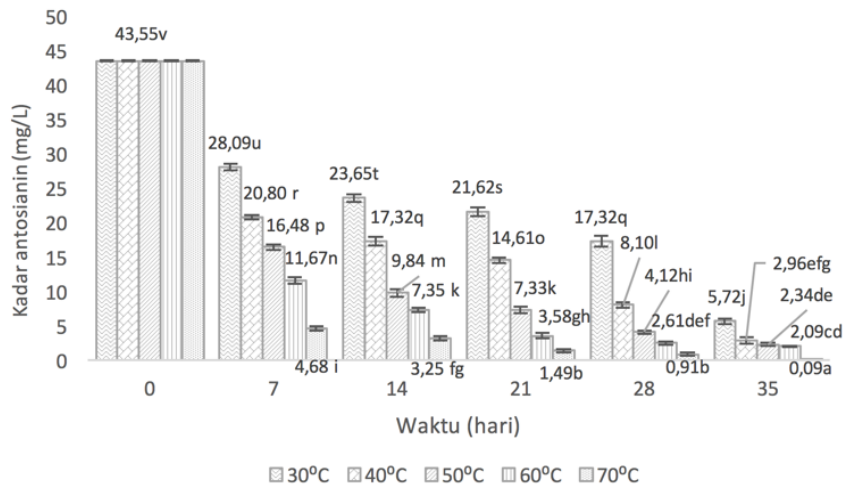

Figur 5. Pengaruh perlakukan suhu $30,40,50,60$, dan $70^{\circ} \mathrm{C}$ pada ekstrak kelopak rosela terhadap kadar antosianin yang disimpan sampai dengan 35 hari.

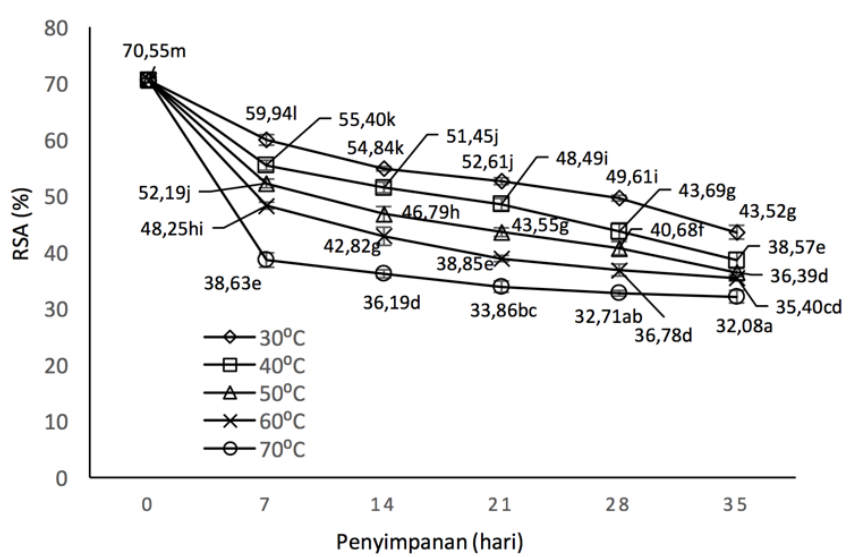

Figur 6. Pengaruh perlakuan suhu $30,40,50,60$, dan $70^{\circ} \mathrm{C}$ terhadap daya antioksidan antosianin pada ekstrak kelopak rosela yang disimpan sampai dengan 35 hari.

Pengaruh Suhu Terhadap Antosianin dan Daya Antioksidan

Seperti yang diungkapkan oleh para peneliti sebelumnya Ma (2012), Sui (2016), dan Markakis (1982) bahwa suhu merupakan salah satu faktor yang dapat mempengaruhi kestabilan antosianin, maka Figur 5 juga memperlihatkan bahwa dalam penelitian ini kandungan antosianin menunjukkan penurunan seiring dengan peningkatan suhu dan lamanya penyimpanan. Peningkatan suhu dan lama penyimpanan dari suhu 30 sampai $70^{\circ} \mathrm{C}$ selama 7 sampai 35 hari menunjukkan perbedaan yang signifikan antara perlakuan.

Penyimpanan pada suhu $30^{\circ} \mathrm{C}$ mulai 0 sampai dengan 35 hari terlihat adanya penurunan kadar antosianin yang cukup tinggi dengan sisa $13,14 \%$; demikian pula pada suhu 40 sampai $70^{\circ} \mathrm{C}$, namun menunjukkan penurunan kadar antosianin yang lebih jauh, masing-masing hanya tersisa 6,$80 ; 5,37 ; 4,81$, dan $0,20 \%$. Pada penyimpanan $70^{\circ} \mathrm{C}$ kadar antosianin pada hari ke 7 sampai 35 tampak menurun sangat tajam dibanding penyimpanan pada suhu yang lebih rendah dengan kadar antosianin $<4,6 \mathrm{mg} / \mathrm{l}$, bahkan pada hari ke 28 dan 35 hanya mengandung antosianin $<1 \mathrm{mg} / \mathrm{l}$ atau $<0,20 \%$. Menurut Markakis (1982); Bridle dan Timberlake (1997); dan Delgado-Vargas (2003); bahwa antosianin menjadi pucat saat pemanasan, karena keseimbangan spesies antosianin bergeser ke arah basis carbinol dan bentuk chalcone yang tidak berwarna.

Beberapa peneliti menegaskan bahwa konsentrasi dan stabilitas warna antosianin menurun pada semua suhu dan dapat semakin cepat pada suhu penyimpanan yang lebih tinggi (Shao-qian et al., 2011; Reyes and Cisneros-Zevallos, 2007; Casati et al., 2015 ; Moldovan et al., 2012; Prommakool and Phattayakorn, 2016; dan Sipahli et al., 2017). Selain itu Markakis (1982) juga menyatakan bahwa suhu selama pemrosesan dan penyimpanan dapat merusak pigmen antosianin walaupun degradasinya tidak terlalu terpengaruh oleh $\mathrm{O}_{2}$ tetapi sangat dipengaruhi oleh akumulasi panas. Pembukaan cincin dan degradasi antosianin menjadi faktor utama yang menyebabkan perubahan warna pada suhu tinggi (He, 2015).

Pembentukan radikal bebas dapat dikendalikan secara alami oleh senyawa yang dikenal sebagai antioksidan (Gholivand, 2014). Seperti yang dijelaskan oleh Santoso (2016), Kouakou et al. (2015), dan Inggrid et al. (2017) bahwa pengujian daya antioksidan suatu senyawa dapat diukur dengan menggunakan radikal bebas DPPH dimana bila bahan antioksidan ditambahkan maka warnanya akan semakin memudar atau memucat karena telah menerima elektron yang disumbangkan oleh senyawa antioksidan dan perubahan ini dapat diukur secara kuantitatif dalam absorbansi $517 \mathrm{~nm}$. Kapasitas antioksidan antosianin ekstrak rosela sebelum dan sesudah penyimpanan pada suhu $30-70^{\circ} \mathrm{C}$ memperlihatkan perbedaan yang nyata $(P>0,05)$ seperti pada Figur 6. Bila dibandingkan dengan Figur 5, maka makin tinggi suhu dan lama penyimpanan menyebabkan kadar antosianin dalam ektrak kelopak rosella semakin rendah demikian pula dengan kemampuannya dalam menangkal radikal bebas. Hal ini menunjukkan bahwa antosianin yang terdapat dalam ekstrak kelopak rosella sangat berperan dalam menangkal radikal bebas, sehingga dapat dikatakan ada keterkaitan yang kuat antara kadar antosianin dengan kemampuan menangkap radikal bebas. Kemampuan antosianin ekstrak kelopak rosella dalam menangkap 
radikal bebas selama penyimpanan pada suhu $30^{\circ} \mathrm{C}$ mulai 0 sampai dengan 35 hari mengalami kemampuan sebesar $45,32 \%$, sedangkan pada $40-70^{\circ} \mathrm{C}$ jauh lebih rendah yaitu $38,57-32,08 \%$ seperti yang terlihat pada Figur 6. Penyimpanan suhu $70^{\circ} \mathrm{C}$ mulai hari ke 7 kemampuan menangkap radikal bebasnya jauh lebih rendah dibandingkan perlakuan lainnya yaitu hanya $38,63 \%$ bahkan sampai akhir penelitian (hari ke-35) yang hanya $32,08 \%$ saja.

Berdasarkan uraian yang telah disampaikan, dapat terlihat bahwa suhu sangat berpengaruh terhadap kemampuan antosianin dalam menangkap radikal bebas. Seperti yang dikatakan oleh Sui (2016), dalam penelitiannya terhadap antosianin ekstrak beras hitam yang disimpan pada suhu 45 dan $65{ }^{\circ} \mathrm{C}$ menunjukkan bahwa kapasitas antioksidannya pada akhir penyimpanan (21 hari) mengalami penurunan secara signifikan $(P<0,05)$. Sui $(2016)$ dan Lestario (2017) menyatakan bahwa antosianin selain dapat digunakan sebagai pewarna alami juga memiliki sifat antioksidan yang kuat.

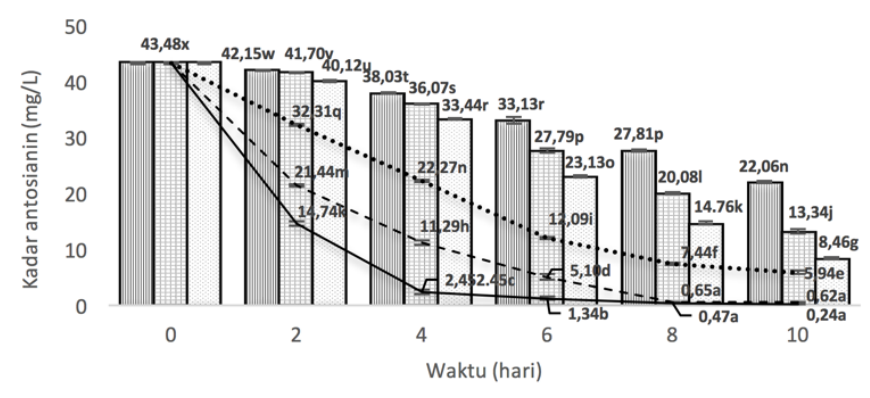

$\square$ Gelap-1478 lux $\square$ Gelap-2835 lux $\square$ Gelap-3940 lux ........Terang-1478 lux - - - - Terang-2835 lux —_Terang-3940 lux

Figur 7 : Pengaruh cahaya 1478, 2835, dan 3940 lux terhadap kadar antosianin ekstrak kelopak rosela pada penyimpanan sampai dengan 10 hari

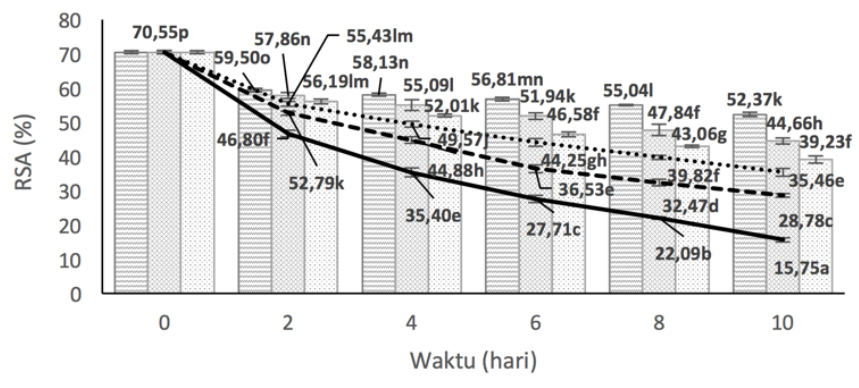

$\circlearrowright$ Gelap-1478 lux $\square$ Gelap-2835 lux $\square$ Gelap-3940 lux ....... Terang-1478 lux ---- Terang-2835 lux —Terang-3940 lux

Figur 8. Pengaruh cahaya 1478, 2835, dan 3940 lux terhadap kemampuan daya antioksidan ekstrak kelopak rosela pada penyimpanan sampai dengan 10 hari.

Pengaruh Cahaya terhadap Antosianin dan Daya Antioksidan

Tidak seperti flavonoid lainnya, antosianin bersifat sangat menyerap cahaya dan dapat memberikan warna bila ditambahkan pada berbagai media (Markakis, 1982). Antosianin kelopak rosela merupakan senyawa flavonoid yang dapat menghasilkan warna merah sampai keunguan. Figur 7 menunjukkan, bahwa paparan cahaya dapat mempengaruhi kandungan antosianin dalam ekstrak kelopak rosela. Bila dibandingkan, maka ekstrak kelopak rosela yang disimpan pada kondisi gelap, kandungan antosianinnya lebih tinggi dibandingkan dengan yang disimpan dalam kondisi terang pada setiap intensitas cahaya yang diberikan, artinya intensitas cahaya yang semakin tinggi dan lama dapat menyebabkan kandungan antosianin semakin menurun. Terlihat adanya perbedaan yang nyata antar hampir semua perlakuan pada taraf signifikansi $95 \%$.

Figur 8 memperlihatkan pengaruh cahaya terhadap kemampuan antioksidan ekstrak kelopak rosela. Intensitas dan aparan cahaya yang semakin tinggi dan lama dapat menyebabkan menurunnya kemampuan ekstrak rosella dalam menangkal radikal bebas. Berdasarkan Figur 7 dan 8, terlihat adanya keterkaitan antara kadar antosianin dan kemampuan menetralisir radikal bebas ekstrak kelopak rosela. Kapasitas antioksidan antosianin telah terbukti karena adanya radikalisasi spesies oksigen reaktif (Faria et al., 2013). Yang (2012) juga menyatakan bahwa ekstrak kelopak rosela memiliki daya antioksidan yang kuat. Seperti yang dinyatakan oleh Lima et al. (2011), bahwa aktivitas antioksidan dapat disebabkan oleh adanya sejumlah besar pigmen antosianin.

Aktivitas antioksidan antosianin berhubungan dengan jumlah hidroksil bebas di sekitar cincin pyrone, dimana semakin banyak hidroksil maka aktivitas antioksidan dapat lebih besar (Miguel, 2011). Semakin mudah suatu senyawa teroksidasi berarti semakin baik kemampuan antioksidannya, karena molekulnya dapat menyumbangkan elektron bebas atau atom hidrogen ke radikal bebas yang reaktif (Castaneda-ovando, 2009). Kouakou (2015) dalam penelitiannya menyatakan bahwa, efektivitas kemampuan antioksidan antosianin kelopak dan kalus rosela lebih tinggi dibandingkan dengan asam askorbat. Antosianin mempunyai hubungan yang erat dengan daya antioksidan (Miguel, 2011).

\section{Kesimpulan}

Frekuensi ekstraksi kelopak rosela lebih baik dilakukan sebanyak 2 kali dengan total kadar antosianin sebesar $89,64 \%$, sedangkan ekstraksi yang ketiga dan keempat prosentasenya menjadi sangat sedikit. Peningkatan suhu dan intensitas cahaya selama penyimpanan dapat menurunkan kadar antosianin dan kemampuan antioksidan ekstrak kelopak rosela. Namun bila dibandingkan dengan pengaruh suhu selama penyimpanan, ternyata cahaya lebih kuat pengaruhnya terhadap penurunan kadar antosianin dan kemampuannya dalam menetralisir radikal bebas. Untuk menghindari kerusakan antosianin dan kemampuan daya antioksidan maka sebaiknya ekstrak kelopak rosela disimpan pada kondisi terhindar dari paparan cahaya atau tertutup dengan suhu rendah.

\section{Ucapan Terimakasih}

Penulis mengucapkan terimakasih kepada Direktorat Jendral Pendidikan Tinggi, Kementerian 
Pendidikan dan Kebudayaan Republik Indonesia yang telah berkenan memberikan bantuan pendanaan sehingga penelitian ini dapat terselenggara dengan baik.

\section{Daftar Pustaka}

Abou-Arab, A.A., Abu-Salem, F.M., Abou-Arab, E.A. 2011. Physico-chemical properties of natural pigments (anthocyanin) extracted from Roselle calyces (Hibiscus sabdariffa). Journal of American Science 7(7): 445-456.

Ali, B.H., Wabel, N.A., Blunden, G. 2005. Phytochemical, pharmacological and toxicological aspects of Hibiscus sabdariffa L.: A review. Phytotheraphy Research 19:369-375. DOI:10.1002/ptr.1628.

Boas, A.C.V., Henrique, P.C., Lima, L.C.O., Neto, A.D. 2014. Antioxidant activity, anthocyanins and organic acids content of grape juices produced in southwest of minas gerais, Brazil. Ciência e Agrotecnologia Lavras 38(5): 480-486. DOI: 10.1590/S1413-70542014000500007.

Bridle, P., Timberlake, C.F. 1997. Anthocyanins as natural food colours-selected aspects. Food Chemistry 58(1-2): 103-109. DOI: 10.1016/S0308-8146(96)00222-1.

Casati C.B., Baeza R., Sanchez V., Catalano A., López P., Zamora MC. 2015. Thermal degradation kinetics of monomeric anthocyanins, colour changes and storage effect in elderberry juices, Journal of Berry Research 5: 29-39. DOI: 10.3233/JBR-150088.

Castaneda-Ovando, A., Pacheco-Hernández, Ma. de Lourdes., Páez-Hernández, Ma. Elena.,Rodríguez, José A., Galán-Vidal, C.A. 2009. Chemical studies of anthocyanins : A review, Elsevier Science B.V. Vol. 113; No. 4 : 859-871. DOI:10.1016/j.foodchem.2008.09.001.

Cissé, M., Bohuon, P., Sambe, F., Kane, C., Sakho, M., Dornier, M. 2012. Aqueous extraction of anthocyanins from Hibiscus sabdariffa: Experimental kinetics and modeling. Journal of Food Engineering 109: 16-21. DOI: 10.1016/j.jfoodeng.2011.10.012.

Da-Costa-Rocha, I., Bonnlaender, B ., Sievers, H., Pischel, I., Heinrich, M. 2014. Hibiscus sabdariffa L. - A phytochemical and pharmacological review. Food Chemistry 165 : 424-443. DOI: 10.1016/j.foodchem.2014.05.002.

Delgado-Vargas, F., Paredes-López, O. 2003. Natural colorants for food and nutraceutical uses, CRC Press. United State of America.

Doyle, M.P. 1980. Experimental Organic Chemistry. John Willey and Sons. Inc., New York.

Elbe, J.H.V., Schwartz, T.J. Colorants. Di dalam: Fennema, Owen. R. 1996. Food Chemistry. New York: Marcell Dekker.

Faria, A., Fernandes, I., Mateus, N., Calhau, C. 2013. Natural Products : Bioavailability of Anthocyanins. Springer-Verlag Berlin Heidelberg. DOI 10.1007/978-3-642-22144-6-75.

Fernandes, I., Faria, A., Calhau, C., de Freitas, V., Mateus, N. 2014. Bioavailability of anthocyanins and derivatives. Journal of Functional Foods 7 . 54-66. DOI: 10.1016/j.jff.2013.05.010.

Gholivand, M.B., Piryaei, M. 2014. Total phenols, flavonoids, anthocyanins, ascorbic acid contents and antioxidant activity of Rhamnus kurdica Boiss for flower and leaves in flowering and preflowering stages. African Journal of Biotechnology 13(10): 1131-1135. DOI: 10.5897/AJB12.2461.

Herrera-Arellano, A., Miranda-Sanchez, J., Avila-Castro, P., Herrera-Alvarez, S., Jimenez-Ferrer, J.E., Zamilpa, A., Roman-Ramos, R., Ponce-Monter, H., Tortoriello, J. 2007. Clinical effects produced by a standardized herbal medicinal product of Hibiscus sabdariffa on patients with hypertension. A randomized, double-blind, lisinopril-controlled clinical trial. Planta Medica 73: 6-12. DOI: 10.1055/s-2006-957065.

HE Xiu-li., LI Xue-li., Yuan-ping L.V., Qiang, H.E. 2015. Composition and color stability of anthocyaninbased extract from purple sweet potato, Food Science and Technology 35(3): 468-473, Campinas. DOI: 10.1590/1678-457X.6687.

Inggrid, H.M, Jaka, Santoso, H. Natural red dyes extraction on roselle petals. 2017. Second International Conference on Chemical Engineering (ICCE) UNPAR. IOP Conference. Series: Materials Science and Engineering 162: 012029. DOI: 10.1088/1757-899X/162/1/012029.

Ioannou, I., Hafsa, I., Hamdi, S., Charbonnel, C. Ghoul, M. 2012. Review of the effects of food processing and formulation on flavonol and anthocyanin behavior. Journal of Food Engineering 111:208217. DOI: 10.1016/j.jfoodeng.2012.02.006.

Janna, O., Khairul, A., Maizah, M., Mohd, M.Y. 2006. Flower Pigment Analysis of Melastoma malabattricum, Journal of African Biotechnology 5 (2):170-174.

Kouakou, T.H., Konkon, N.G, Ayolié, K., Obouayeba, A.P., Abeda, Z.H., Koné, M. 2015. Anthocyanin production in calyx and callus of Roselle (Hibiscus sabdariffa L.) and its impact on antioxidant activity. Journal of Pharmacognosy and Phytochemistry 4(3): 09-15.

Lestario, N.L. 2017. Antosianin : Sifat kimia, Perannya dalam kesehatan, dan Prospeknya sebagai Pewarna Makanan. Gadjah Mada University Press. Yogyakarta. Indonesia.

Lima, A.D.J., Corrêa, A.D., Saczk, A.A., Martins, M.P., Castilho, R.O. 2011. anthocyanins, pigment stability and antioxidant activity in Jabuticaba [Myrciaria cauliflora (Mart.) O. Berg]. Revista Brasileira de Fruticultura 33 (3):877-887. DOI: 10.1590/S0100-29452011000300023.

Ma, C., Yang, L., Yang, F., Wang, W., Zhao, C., Zu, Y. 2012. Content and color stability of anthocyanins isolated from Schisandra chinensis fruit. International Journal of Molecular Sciences 13: 14294-14310. DOI:10.3390/ijms131114294.

Mahfud, T. 2018. Ekstraksi pewarna alami kelopak bunga rosella (Hisbiscus sabdariffa) pada pembuatan minuman serbuk instan rosella. Jurnal 
Sains Terapan No. 1 (1). DOI: 10.32487/ jst.v1i1.29.

Markakis, P. 1982. Anthocyanin as food colors. Academica Press. New York : 214-266.

McKay, D.L., Chen, C.Y.O., Saltzman, E., Blumberg, J.B. 2010. Hibiscus sabdariffa L. Tea (Tisane) lowers blood pressure in prehypertensive and mildly hypertensive adults. The Journal of Nutrition. 140: 298-303. DOI:10.3945/jn.109. 115097.

Mokrzycki W.S., Tatol M. 2012. Colour difference $\Delta \mathrm{E}$ - A survey. Faculty of Mathematics and Informatics University of Warmia and Mazury, Sloneczna 54, Olsztyn, Poland.

Moldovan B., David L., Chişbora C., Cimpoiu C. 2012. Degradation kinetics of anthocyanins from european cranberrybush (Viburnum opulus L.) fruit extracts. Effects of temperature, $\mathrm{pH}$ and storage solvent. Molecules 17:11655-11666. DOI: 10.3390/molecules171011655.

Patras, A., Brunton, N.P., O'donnell, C., Tiwari, B.K. 2010. Effect of therma processing on anthocyanin stability in foods; Mechanisms and kinetics of degradation a review. Trends in Food Science \& Technology 21:3-11. DOI: 10.1016/j.tifs.2009. 07.004 .

Prommakool, A., Phattayakorn K. 2016. The Storage stability of anthocyanins in Mao (Antidesma thwaitesianum Müll. Arg.) juice and concentrate. MATEC Web of Conferences. 62: 02006. ICCFE. DOI: 10.1051/ matecconf/ 20166202006.

Reyes, L.F., Cisneros-Zevallos, L. 2007. Degradation kinetics and colour of anthocyanins in aqueous extracts of purple and red flesh potatoes (Solanum tuberosum L.). Food Chemistry 100:885-894. DOI: 10.1016/j.foodchem.2005.11.002.

Santoso, U. 2016. Antioksidan Pangan. Gadjah Mada University Press. Yogyakarta.

Shao-qian, C.A.O., Liang, LIU., Si-yi, P.A.N. 2011. Thermal degradation kinetics of anthocyanins and visual color of blood orange juice. Agricultural Sciences in China 10(12): 1992-1997. DOI: 10.1016/S1671 2927(11)60201-0.

Shin, S., Bhowmik, S.R. 1995. Thermal kinetic of colour changes in pea puree. Journal of Food Engineering 24(1): 77-86. DOI: 10.1016/02608774(94)P1609-2.
Sindi, H.A., Marshall, L.J., Morgan, M.R.A. 2014. Comparative chemical and biochemical analysis of extracts of Hibiscus sabdariffa. Food Chemistry 164:23-29. DOI:10.1016/j.foodchem.2014. 04.097.

Sipahli, S., Viresh, M., Jason, M.J. 2017. Stability and degradation kinetics of crude anthocyanin extracts from $H$. sabdariffa. Food Science and Technology 37(2):209-215. Campinas. DOI:10.1590/1678$457 X .14216$.

Sui, X., Bary, S., Zhou, W. 2016. Changes in the color, chemical stability and antioxidant capacity of thermally treated anthocyanin aqueous solution over storage. Food Chemistry 192: 516-524. DOI: 10.1016/j.foodchem.2015.07.021.

Sayago-Ayerdi, S.G., Arranz, S., Serrano, J., Goni, I. 2007. Dietary fiber content and associated antioxidant compounds in roselle flower (Hibiscus sabdariffa L.) beverage. Journal of Agriculture Food Chemistry 55:7886-90. DOI: 10.1021/ jf070485b.

Sindi, H.A., Marshall, L.J., Morgan, M.R.A. 2014. Comparative chemical and biochemical analysis of extracts of Hibiscus sabdariffa. Food Chemistry 164:23-29. DOI: 10.1016/j.foodchem.2014. 04.097.

Vatai, T., Skerget, M., Knez, Z., Kareth, S., Wehowski, M., Weidner, E. 2008. Extraction and formulation of anthocyanin-concentrates from grape residues. Journal of Supercritical Fluids 45:32-36. DOI: 10.1016/j.supflu.2007.12.008.

Wells, M.J.M. 2003. Principles of extraction and the extraction of semivolatile organics from liquids. Sample Preparation Techniques in Analytical Chemistry 162:37.

Wrolstad, R.E., Terry, E.A., Eric, Decker, A., Michael, H.P., David, S.R., Steven, J.S., Charles, F.S., Denise, M.S., Peter, S. 2005. Handbook of Food Analytical Chemistry. Wiey Interscience., Publication. New Jersey.

Yang, L., Gou, Y., Zhao, T., Zhao, J., Li, F., Zhang, B., $\mathrm{Wu}, \mathrm{X} .2012$. Antioxidant capacity of extracts from calyx fruits of roselle (Hibiscus sabdariffa L.). African Journal of Biotechnology 11(17):40634068. DOI:10.5897/AJB11.2227. 